\title{
Using Effective Factors in Employees Empowerment of Industrial Organizations with Analytic Network Approach (ANP) Case Study: Textile Factories of Qom Province
}

\author{
Hamideh Shekari \\ Management Department, Payame Noor University, Taft, Yazd , I. R. of Iran \\ E-mail: L_shekari60@yahoo.com
}

Ali Rabiee

Assistant Professor of Payame Noor University, Tehran, Iran

E-mail: alirabiee@csr.ir

Mohamad Ali Afshari (Corresponding author)

Master of Operations Management, Kar University, Science Department, Qazvin, Iran.

Tel: +98-938-202-9618Ｅ-mail: mohamadaliafshari@yahoo.com

Mona Ahani

Master of Public Management, Islamic Azad University of Naragh

E-mail: mona.ahani@yahoo.com

Received: April 9, 2011 Accepted: May 17, 2011 doi:10.5430/ijba.v2n3p160

\begin{abstract}
Empowering employees should be one of the most important tasks of organization in competitive benefits and its living. Empowering can be counted as the golden key in exploiting all physical and mental abilities of the most important investment meaning human being. Organization regarding complex environment of outside are the powers that can quickly give positive answer to the external environment and this item is not be produced with empowerment. In this research which is gathered in weaving factories, we will pay attention to the discussion about the importance of the issue with studying the literature of research and its background.

In the next step, the most important factors were recognized and arranged through interviewing the specialized individuals and providing questionnaires. In the questionnaire of research, the factors that their average were higher than 2, were educed as the final effective factors. In this study, three principle factors along with the secondary factors were recognized and assigned. The principle assumption in this study is the connection of factors with each other. Finally, using analytic network approach, principle factors in empowering employees were recognized and at the final, the results and suggestions will be provided.
\end{abstract}

Keywords: Empowering, Analytical Network Process, Industrial Organizations, MCDM.

\section{Introduction}

Employees' education and empowerment are one of aims of organizations and they were always stabilized on theses propaganda that enjoyment is in the group of intelligent, educated and high powered employees. Educational periods on the job, short period and long period or in other ways, individual and collective capacities and abilities are along organizational aims. After many years' experiments, the world is reached to this result that if a organization want to pioneer in active affair and economy and don't evacuate in the field of competition, it should specialized, genius and motivational human being forces. Human resources form real riches of an organization, in other words, empowerment is the guidance of advancement and organizational prosperity. 
Employees' empowerment is turned to one of remarkable contexts in theories and contemporary functions of management (Gary et al., 1998). Most of organizations follow to actuality of potential ability of their employees through their empowerment. Empowerment in organization in many cases is by delegation (Innocent, 1994).

Empowerment has different definitions. For example, Vogt (1997) defines empowerment as following sentence: it is a science that lets employees to have a role in decision making in the environment of their job and it is accompanied with increase of individual independence and self-determination in decision making. In other definition (Morales, 1997) it is that: empowerment is along with confidence to each other, support, respect and creating motivation in development and improvement of skills. The other definition is that: empowerment (Blanchard, 1997) is to break traditional structure of hierarchism and give the authorization and right of decision making to hierarchal employees being involved in solving problem.

But today, empowerment has more extended context and is not involved in delegation; rather it is a process that personal can improve their function by learning knowledge, skill and motivation (Nahidi and others, 2008). Whetten \& Comeron (1998) say that: empowerment means to strengthen employees, intending to help them in order for relay on their self-confidence and overcome on their inabilities or desperation as well as to give energy and internal motivation for executing activities.

Thomas \& Velthouse (1990) provide more complete definition of empowerment: psychological empowerment is as a complex of motivational cognitive domains that in addition to be self- working involves three other cognitive: feeling self-determination, being meaningful and being effective.

Concerning mechanical and organizational approach, Fox (1998) paid attention to define this word. With him, mechanical approach is to delegate responsibilities and accounting in order for taking responsibilities. But organizational approach is conversation of adventuring, growth, change, perceives employees' needs, collaborating in order for motivating behaves based on collaboration, motivating intelligent adventuring and relying on employees' function.

Concerning managerial and organizational researches, empowerment can be divided in to three groups: 1 . Empowerment as delegation. 2. Empowerment as motivation. 3. Empowerment on the basis of two approaches of organic and mechanic.

Organizations can guarantee their living in the dynamic and changeable environment of today that educate knowledgeable and effective forces and use them as an efficient tool in changes of environment in appropriate time. Observable companies regarding world competitions and entrance of importable goods need employees to show standing and to keep their living in front of changes by assured knowledge and flexible structure. So in this operational research, we seek to ask that what factors have role in empowerment of employees in these industrial organizations, especially in weaving industry?

Empowerment in all situations guarantee success and its effectiveness is in the guaranty of consistency with needs, aims, culture of organization, structure and attitude of employees. Hence, it is necessary that organization try to improve its effectiveness by recognition of effective factors on empowerment (Rahnamood and Husseini, 2008).

In fact, empowerment of employees is to give actual authority to employees for continues improvement and job satisfaction in the function of organizations which cause to produce productions and provide serving to customers as well as creation of competitive benefits. Empowerment has direct relation with lack of focus in organization. So empowerment of employees can be attended by giving authority for the right of decision making to employees and lack of reference of works to high levels of organization. In most of researches (Menon, 1995), researchers believe that selfconfidence in great jobs cause to register it, grow behave and satisfaction of working.

With regard to organizational perspective in relation with empowering employees, the matter seems that how the power can be shared with other parts of organization. In fact, movement of power from high level of organization to low level is organizational hierarchy. Effective key in achievement of employees' empowerment in order for improvement is such that every person in the organization should have definite perceive from empowering in organization; that to what aim does he want to reach?

For minimizing fault in the process of empowering personal is necessary for the obligation of influential mangers and leaders in organization, all-out participation of employees, providers, consumers and all-out connections.

This research tended to study effective factors in empowering employees of weaving industry in the province of Qom. We inclined to present research model and then deduce in the continuance of accomplished researches in the inside and outside of country. 


\section{Research Literature}

\subsection{Background of Research}

For perceiving necessity and importance of empowerment, attention to its benefit in new environmental situation is necessary. Environmental evolutions such as technological improvement, flatten of organizations and elimination of middle layers in addition to need to optimizing capacity of individual is concurrent with reduction of human forces augment the importance of empowerment.

By assessment of empowering employees' through on-the-job education in refinery of Esfahan, Naderi and others (2008) found that creating on the job educations would have rightful effect in empowering employees.

Rahnavard and Husseini (2008) studied effective factors on empowering women in the company of telephone and found that four factors on the title of attitude of management, group structure, values of inter group and data relations were recognized as the effective factors in empowering women employees in Iran Company of telephone.

Burdett (1991) regarded three factors in the achievement of empowering employees. They are as follow: management based on education; jobs with wider realm; establishment of organization.

Menon (19955) in a research which was done on 311 employees found that focus, formality, weak communications, ambiguity in role and opposition of role cause to reduce individual empowerment in the organization.

Studying on 52 banks, Leon \& Thomas (1996) found that role is very effective and important in empowering employees.

Result of Spreitzer's research (1996) shows that employees being empowered have more achievement to information and their working is more participative in comparison with traditional organizations.

\section{2 Models of Empowering Employees}

Jaffe, D.T., and Scott, C.D. (1992) considered the following model for empowering employees. This model involves four principal elements that are shown in Figure 1.

$<$ Figure 1 about here $>$

The other model associated to Kinlaw (1995) that in this model empowerment cause to continuous improvement.

Figure 2 shows this model.

$<$ Figure 2 about here $>$

Figure 3 shows empowerment of women employees in the company of Telephone that was done by Rahnamood and Husseini (2008).

$<$ Figure 3 about here $>$

Figure 4 shows model of empowerment of pilgrimage managers that was verified by Asgari (2004)

$<$ Figure 4 about here $>$

Indeed, it should be regarded that all of these models concerning situation of studied organizations are defined and designed and it can not be prescribed as a per-determined transcript for other organizations. Since essence of human being is complex, organizational structures and theoretical models would change so widely and this entails continuous researches in relation of human matters especially in the field of empowering employees.

\section{Analytic Network Process}

In the premier researches being accomplished, analytic network process was used as a multi-criterion decisional technique for solving complex decisional problems (Yuksel, 2007). Sa'ati introduced AHP for the first time and used it for complex problems (Bozdag et al., 2003) and (Kahraman et al., 2006). The principal assumption in AHP is independence of higher levels in comparison with lower levels as well as criterions and other factors in every level.

Most of decisional problems are not ranged since extent of bilateral relation between different factors is heretical. Sa'ati suggested using AHP for solving problems because there is not any relation between alternatives and criterions; also when movements and indexes are associated to each other, ANP is used. ANP is proposed as a mode of extended AHP, while in AHP, relations are hierarchically sidelong; and in ANP, relations between indexes and decisional levels are bilateral.

Feedback process of ANP uses a network of relations between levels rather than using hierarchism. In this network, it can not simply be distinguished that what levels are higher or lower, dominant or subordinate, direct or indirect (Meade, 1999). For example, not only criterions are effective on the importance of alternatives, but also alternatives are effective 
on the importance of criterions. Hence, hierarchical structure with a linear relation towards low is not suitable for a complex system.

\subsection{Steps of Analytic Network Process (ANP)}

Step one: creation of model and formulation of matter.

Decisional indexes and possible alternatives are distinguished in the step of making model and aim of deciding (Schenkerman, 1994).

Step two: performance of couple and computational comparisons.

In this step, a serious of couple comparisons is accomplished for achievement of comparative importance that every one is one of effective factors and indexes for selecting aim. In these comparisons, a comparative criterion is used from 1 to 9 in order to compare two factors. Score of 1 is equivalent with two factors, while score of 9 shows the complete overcome of factor (element of raw) in comparison with other factor (element of column). In invert comparison, an invert value is automatically distinguished, that is: $A_{i j} \times A_{j i}=1$

This comparison is according to suggested way (Tolga, 2005). Cooperative decision making might be used in order to avoid from any tendentious attitude in the formulation of dual comparisons Matrix. Dyer and Forman (Dyer, 1992) suggested various methods for considering attitudes and adjust of group members in dual comparisons Matrix that are as following: 1. consensus; 2. vote or compromise; 3. geometrical average of individual adjustment; 4. separate model.

Step three: accomplishment of dual comparison Matrix for internal and feedback dependents.

In this step, internal weight of indexes and sub-indexes being distinguished in the step of making models are accounted. In this step like previous step, we have dual comparison matrix, with this different that in this step internal and feedback dependents are considered.

Step four: formulation of super matrix

Super matrix is used for analysis of bilateral independents between system parts. Parts of super matrixes results from dual comparisons of internal independents and is replaced in it. Any value except zero shows the comparative importance of weight of internal independents of dual comparisons matrixes.

In the next step, super matrixes are used for convergence and achievement to a serious of long term stable weights. In order to achieve this aim, any column of matrix should be in the form of probable vector. To the power of super matrix cause convergence and its power should be as follow: 2k-1 ( K is a capital letter and optional), (Agarwal, 2003).

Step Five: selection of the best decision.

In this step, total weight of replacements is achieved by factoring achieved weights of any distinguished pervious steps and it is taken regarding final decision.

\section{Theoretical Frame of Research}

In this research that is accomplished by analytic network process on industrial-weaving factories of Qom, population of this research involves managers of these units as well as experts associated to attraction, employment and part of research and development that their numbers are 21members.

Sample of this study involves 21 numbers that assess in two steps by the method of judgmental sampling. In the first step, the experts of research selected the most important ones among the effective factors on the empowerment employees being gathered from different sources. In the next step, they did the hierarchy operation through association. This study is operational too.

Research steps were fulfilled step by step:

Step one: in this step, 45 indexes being gathered from different sources are assessed by experts with questioners. Three numbers of 1, 2, 3 that shows very important, a little important and important are used in assessment of factors. Assessment of decision makers were combined by accounting average and 12 factors were selected with the higher score of 2.12 factors were arranged in three groups of organization, individual and occupation.

With regard to aforesaid mentions, the effective factors on empowering employees can be explained in a total issue.

Organizational factors are as following:

1. Determination of aims, responsibilities and authorities in organization: employees should know about their responsibilities, explanation of their task, aim and commission of organization, steps as well as its working processes. 
2. Enrichment of employments and improvement of employees' job: organization should proceed in order to develop technical information and specialization of employees and raise of their occupational content. Also it should use working circulation in order to fulfill principle of replacement in the organization.

3. Environment of job: Environment of job is among effective factors being emphasized in organizations. Attention to security and health of employees in the Environment of job, creation of suitable situations towards occupational development of employees, reduction of tension and existent tension in the Environment of job can be associated to the Environment of job.

4. Reduction of supervision: if employee would be a little under supervisor's eyes and has enough authority, empowerment will be better.

5. Education on the job: with regard to research literature, education has very important role in empowering employees. In fact, empowerment is one of very important factors in empowering individuals in the organization.

Individual factors are:

\section{Cooperation and team working:}

Using ideas of employees in making decisions and their cooperation, advancement of organizational affairs, delegation to employees in different levels, employees' participation in representing suggestions in order to do affairs and control proceeded affairs by employees can be as the factor of participation in empowering employees in organizations.

2. Organizational belonging and mood:

In order to fulfill this factor, employees should be respected in organization and be assisted in solving their individual problems. Suitable backgrounds should be provided for employees so that they can represent their innovation, invention and creativity and the super manager assure that employees attend to do affaires being conceded to them.

3. Recognition and appreciation:

Proportion of salary, wage and taken reward with a work that employees do, suitable distribution of facilities in organizations and proportion of job development of employees along with their aptness can cover the propound factor in organization.

4. Occupational information, knowledge and skill: for providing this factor, facilities of developing occupational skills in organization, background of effective and efficient education in organization and having technical and specialized information about posts can be useful.

Occupational factors are:

1. Occupational background; 2. Occupational tedium.3. Role Conflicts

$<$ Figure 5 about here $>$

Step two: ANP is formed by the principle and secondary factor in the first step.

Step three: in this step, comparative weight of principle factors and secondary factors in the second and third levels are accounted. Matrix of dual comparisons is constituted by experts. For example, organizational factor and secondary factor is compared by this question that what is scale of importance of organizational factor in comparison with secondary factor?

For example, scale of organizational factor being more important with secondary factor is shown with the number 7 (Table 1)

Rest of other matrixes of assessment is constituted as the follow and their weight are accounted. Other matrixes of dual comparisons and their comparative weights are shown in tables 2 and 5 .

$<$ Table 1 about here>

$<$ Table 2 about here $>$

$<$ Table 3 about here $>$

$<$ Table 4 about here>

$<$ Table 5 about here $>$

$<$ Table 6 about here>

$<$ Table 7 about here> 
Step four: in this step, weights of bilateral dependents of factors, account of dependents among factors are considered. Dependent among factors are accounted through assessment of effect degree of every factor on other factors. On the basis of showed dependents in the second level of figure 1, dual comparison of matrix is created for factors (tables 6 to 8).

$<$ Table 8 about here $>$

For example, number of 5 (more important) in table 6, is achieved through this question that: what is the importance of individual factors' effect on organizational factors beside occupational factors?

The final column of tables 6 and 8 is associated to comparative importance of weights.

Matrix of dependency is formed by comparative importance of weights. Bilateral weights of dependency of factors are achieved by factoring matrix of dependency factors in table 6 to 8, in the weight of factors (table 2) and normalization. Weight of bilateral dependency relations are accounted as the following:

$\left(\begin{array}{ccc}1 & .75 & .83 \\ .83 & 1 & .17 \\ .17 & .25 & 1\end{array}\right) \times\left(\begin{array}{l}.595 \\ .128 \\ .276\end{array}\right)=\left(\begin{array}{l}.46 \\ .31 \\ .23\end{array}\right)$

As it was shown, there is clear difference between achieved factors (table 2) and weights of bilateral dependency.

Step five: by the weights of bilateral dependency (step 4) and comparative weight of secondary factors (step 3), the final weight of secondary factors are accounted. Final weight of secondary factors is accounted through comparative weight of secondary factors in the weight of bilateral dependency being belonged to them. The achieved weights have been mentioned in table 9. On the basis of final weight of secondary factors, secondary factors (occupational enrichment, cooperation, occupational background and occupational tedium) have been recognized as the most important effective factors in systematic fault. It is necessary to say that occupational tedium is the negative and unacceptable factor in empowering employees. In fact, we should try to reduce occupational tedium so that to create employees with normal empowerment.

$<$ Table 9 about here $>$

\section{Discussion and Conclusion}

As it was mentioned in previous chapters, empowerment of employees is using the potential capacities of employees that has not been enough used till now. Results of research shows that organizational factors in comparison with other factors has more importance in creation of employees empowerment and after that, individual factors and occupational factors is important. Among individual factors, occupational background and its enrichment as well as its tedium in empowerment of employees has more importance.

Individual factor of occupational enrichment is associated to organizational factor and individual factor of cooperation is associated to individual factor and individual factor of occupational background is associated to occupational factor. In many organizations like studied organizations in this research, expensive costs is spent for administrative and control and inspection, whereas with occupational enrichment and development of cooperative plans for improvement of skill level and situation of job can assist employees and organization for empowering.

The following cases are among the accomplishments that empowered organizations can get to fulfill these factors:

Customer satisfaction and its increase, being coextensive with market needs, occupational satisfaction of employees, increase of belonging, cooperation and responsibility of employees, change of perception way of compulsion to authorization, more obligation of employees and improvement of quality in jobs, better relation between employees and managers, supervisors and.... Of course there are many impediments for empowering that organizations by recognition of these impediments can step effectively towards empowerment.

Fulfillment of empowering factors in organizations is very useful and brings about increase of productivity of organization and employees. Necessity of fulfilling this technique needs super managers' support, cooperation with employees and administrative factors in advancement of affairs. Among administrative impediments, these factors are:

Domination of formal and hierarchical structure, low of reliance and assurance of organizational members to each other, unsuitable attitude of managers to employees and management styles, unsuitable leadership, lack of necessary skills in employees, many differences among individuals in organization, existent of non-concordant personal systems and tension and stress in working environment. 
In order to empower employees in organization, initiative and suitable constitution is needed in the environment of organization. In organizations that effective factors are correctly fulfilled in empowerment, it should be assured that the best use of humane forces is done at the result of the most productivity in organizations.

By executing changes, this model can be used in other companies. In the suggested model of this research, there is dependency and relation in the first step among the most important factors, whereas in the next studies, dependency and relation can be established in the secondary factors of the suggested model. Also, in order to analyze and examine the matter, other techniques like DEMATEL, DEMATEL Fuzzy or ANP can be used.

\section{References}

Agarwal, A., Shankar, R., 2003. On-line trust building in e-enabled supply chain. Supply Chain Management: An International Journal; 8(4):324-34. doi:10.1108/13598540310490080, http://dx.doi.org/10.1108/13598540310490080

Belanchard, Karloos and Randolf., 2002.management of empowering employees, translator: PhD Mahdi Iran Nejad, managers' press.

Blanchard , K.Carlos,J.P,\&Randolph,A.,(1996) Empowerment Takes more than a Minute, Sanfaroncisco: Barrett KoehlerPublishers. Inc. p. 68.

Blanchard, K. (1997). Out with the old and in with the new. Incentive. 171(4), pp. 59-61.

Bowen, D.E. and Lawler, E.E. (1992) The Empowerment of Service Workers: What, Why, How and When?, Sloan Management Review, Vol. 31 spring, pp.31-9.

Bozdag, C.E., Kahraman, C., Ruan, D., 2003. Fuzzy group decision making for selection among computer integrated manufacturing systems. Computers in Industry 51 (1), 13-29. doi:10.1016/S0166-3615(03)00029-0, http://dx.doi.org/10.1016/S0166-3615(03)00029-0

Burdett, J.O. (1991) What Is Empowerment Anyway?', Journal of European Industrial Training, Vol. 15, No. 6, pp. 23-30.

Denis, T. Jef/ Sindia D. Scott, skill of super management, empowerment of employees is a field for empowered management, Translator: PhD Behzad Ramezani, square press (1998).

Dyer RF, Forman EH., 1992. Group decision support with the analytic hierarchy process. Decision Support Systems; 8(2):99-124. doi:10.1016/0167-9236(92)90003-8, http://dx.doi.org/10.1016/0167-9236(92)90003-8

Eskandari, Mojtaba, (2004), design of systematic model for empowering managers, quarterly of instructor of human science, No 2, P 53.

Fox ,J.(1998) Employee Empowerment: An Apprenticeship Model , Barney School of Business University Hartford,Available: (http:// members: tripod. Com).

Gary D., Phillip C., and Joan A., (1998), "Strategic performance empowerment model", Empowerment in Organizations, Vol. 6 No. 2, 1998, pp. 57-65. doi:10.1108/14634449810210742, http://dx.doi.org/10.1108/14634449810210742

Gizla Hagman, motivation and management of evolution, Translator: Ali Mohammad Godarzi, press of Ressa institute (2001).

Innocent, E. (1994), "Empowering Disadvantaged Employees" Empowerment $\quad$ in Organisation, Vol. 2 No. 1, pp. 31-37. doi:10.1108/09684899410054661, http://dx.doi.org/10.1108/09684899410054661

Jaffe, D.T. and Scott, C.D. (1992) Empowerment: Building a Committed Workforce, New York: Kogan Page, December.

Jharkharia, S., Shankar, R.,2007. Selection of logistics service provider: An analytic network process(ANP) approach., Omega 35, 274 - 289. doi:10.1016/j.omega.2005.06.005, http://dx.doi.org/10.1016/j.omega.2005.06.005

Kahraman, C., Ertay, T., Buyukozkan, G., 2006. A fuzzy optimization model for QFD planning process using analytic network approach. European Journal of Operational Research 171, 390-411. doi:10.1016/j.ejor.2004.09.016, http://dx.doi.org/10.1016/j.ejor.2004.09.016

Kinlaw, D.C. (1995), "The Practice of Empowerment: Making the Most of Human Competence", Gower, Hampshire.

Luise, M. (1995), " Theorizing empowerment in the UK public services", Empowerment in Organizations Volume $3 \cdot$ Number 3 • pp. 35-41. 
Menon, S.T. (1995), "Employee Empowerment: Definition, Measurement and University, Canada.

Morales, O. (1997), The flip side, Business Mexico, 7(7), pp. 32-33.

Naderi, Nahid, Jamshidian, Abdo al-Rasool and Ghorban Ali, Salimi (2008), empowerment of employees through on the job educations, paper of society for management, No 27, P 114

Nick, N., Jack L. Simonetti, Warren R. Nielsen and Barbara Welling., (1994), "Employee Empowerment", Empowerment in Organizations, Vol. 2 No. 3, pp. 45-55. doi:10.1108/09684899410071699, http://dx.doi.org/10.1108/09684899410071699

O'Brien, M. and Whitmore, E., “Empowering women students in higher education”, McGill Journal of Education, Vol. 24 No.3, 1989, pp. 305-20.

Saaty, T.L., Takizawa, M., 1986. Dependence and independence: from linear hierarchies to nonlinear Networks. European Journal of Operational Research 26, 229-237. doi:10.1016/0377-2217(86)90184-0, http://dx.doi.org/10.1016/0377-2217(86)90184-0

Schenkerman, S., 1994. Avoiding rank reversal in AHP decisionsupport models. European Journal of Operational Research;74(3):407-19. doi:10.1016/0377-2217(94)90220-8, http://dx.doi.org/10.1016/0377-2217(94)90220-8

Spreitzer, G. (1992), “'When organisations dare: the dynamics of individual empowerment in the workforce", Doctoral dissertation, University of Michigan.

Thomas, K, W, Velthouse B. A. (1990) Cognitive Elements of Empowerment: An Interpretive Model of Intrinsic, Task Motivation, Academy of Management Journal v15 . N4 . p. 666-681.

Tolga, E., Demircan, M.L., Kahraman, C., 2005. Operating system selection using fuzzy replacement analysis and analytic hierarchy process. International Journal of Production Economics 97, 89-117. doi:10.1016/j.ijpe.2004.07.001, http://dx.doi.org/10.1016/j.ijpe.2004.07.001

Vogt, P. (1997), Transfer of power, Credit Union Management, 20(6), pp. 44-45.

Whetten . P. A. \& Kim . S. Comeron . (1998) Developing Management Skills, New York: Addison-Wesley, Wheelan.

Yuksel, I., Dagdeviren, M., 2007. Using the analytic network process (ANP) in a SWOT analysis - a case study for a textile firm. Information Science 177 (16), 3364-3382. doi:10.1016/j.ins.2007.01.001, http://dx.doi.org/10.1016/j.ins.2007.01.001

Table 1. Principle scale of definitive numbers

\begin{tabular}{|l|l|}
\hline Degrees of Importance & Definition \\
\hline 1 & Equal important \\
\hline 3 & A little important \\
\hline 5 & Important \\
\hline 7 & Very important \\
\hline 9 & Extraordinary important \\
\hline $2,4,6,8$ & Median degrees \\
\hline
\end{tabular}

Table 2. Matrix of dual comparison of principle factors and comparative importance of any factor

\begin{tabular}{|l|l|l|l|l|}
\hline $\begin{array}{l}\text { Comparative } \\
\text { Importance }\end{array}$ & JRF & PF & OF & Factors \\
\hline 0.595 & 2 & 5 & 1 & OF \\
\hline 0.128 & $1 / 2$ & 1 & $1 / 5$ & PF \\
\hline 0.276 & 1 & 2 & $1 / 2$ & JRF \\
\hline CR $=0.01$ & \multicolumn{5}{|l}{} \\
\hline
\end{tabular}


Table 3. Matrix of dual comparison of organizational secondary factors and comparative importance of any secondary factor

\begin{tabular}{|c|c|c|c|c|c|c|}
\hline $\begin{array}{c}\text { Comparative } \\
\text { Importance }\end{array}$ & LF & RCF & INF & JR & AC & Factors \\
\hline 210. & 2 & 3 & 3 & $1 / 3$ & 1 & AC \\
\hline 0.5210 & 3 & 8 & 8 & 1 & 3 & JR \\
\hline 0.067 & $1 / 2$ & 1 & 1 & $1 / 8$ & $1 / 3$ & INF \\
\hline 0.670 & $1 / 2$ & 1 & 1 & $1 / 8$ & $1 / 3$ & RCF \\
\hline 0.13 & 1 & 2 & 2 & $1 / 3$ & $1 / 2$ & LF \\
\hline CR $=0.01$
\end{tabular}

Table 4. Matrix of dual comparison of individual secondary factors and comparative importance of any secondary factor

\begin{tabular}{|c|c|c|c|c|c|}
\hline $\begin{array}{c}\text { Comparative } \\
\text { Importance }\end{array}$ & ISF & CF & BF & PGF & Factors \\
\hline 0.551 & 4 & 3 & 7 & 1 & PGF \\
\hline 0.060 & $1 / 3$ & $1 / 4$ & 1 & $1 / 7$ & BF \\
\hline 0.260 & 3 & 1 & 4 & $1 / 3$ & CF \\
\hline 0.129 & 1 & $1 / 3$ & 3 & $1 / 4$ & ISF \\
\hline $\mathrm{CR}=0.05$
\end{tabular}

Table 5. Matrix of dual comparison of occupational secondary factors and comparative importance of any factor

\begin{tabular}{|c|c|c|c|c|}
\hline $\begin{array}{c}\text { Comparative } \\
\text { Importance }\end{array}$ & RC & MON & TC & Factors \\
\hline 0.637 & 5 & 3 & 1 & TC \\
\hline 0.258 & 3 & 1 & $1 / 3$ & MON \\
\hline 0.105 & 1 & $1 / 3$ & $1 / 5$ & RC \\
\hline $\mathrm{CR}=0.04$
\end{tabular}

Table 6. Matrix of internal dependency of factors concerning organizational factors

\begin{tabular}{|c|c|c|c|}
\hline Organizational Factors & Individual Factors & Occupational Factors & Weights of Comparative Importance \\
\hline Individual Factors & 1 & 5 & 0.83 \\
\hline Occupational Factors & $1 / 5$ & 1 & 0.17 \\
\hline
\end{tabular}

Table 7. Matrix of internal dependency of factors concerning Individual factors

\begin{tabular}{|c|c|c|c|}
\hline Individual Factors & $\begin{array}{c}\text { Organizational } \\
\text { Factors }\end{array}$ & $\begin{array}{c}\text { Occupational } \\
\text { Factors }\end{array}$ & $\begin{array}{c}\text { Weights of Comparative } \\
\text { Importance }\end{array}$ \\
\hline Organizational Factors & 1 & 3 & 0.75 \\
\hline Occupational Factors & $1 / 3$ & 1 & 0.25 \\
\hline
\end{tabular}

Table 8. Matrix of internal dependency of factors concerning Occupational factors

\begin{tabular}{|l|l|l|l|}
\hline Individual Factors & Organizational Factors & Occupational factors & Weights of comparative importance \\
\hline Organizational Factors & 1 & 5 & $0 / 83$ \\
\hline Individual Factors & $1 / 5$ & 1 & $0 / 17$ \\
\hline
\end{tabular}


Table 9. Total accounted weights of individual factors

\begin{tabular}{|c|c|c|c|}
\hline Factors and Comparative Weights & Secondary Factors & Comparative Factors & Total Weights \\
\hline \multirow[t]{5}{*}{$\begin{array}{l}\text { Organizational Factors } \\
0 / 46\end{array}$} & To distinguish aims & $0 / 210$ & $0 / 10$ \\
\hline & Enrichment of Jobs & $0 / 521$ & $0 / 24$ \\
\hline & Environment of job & $0 / 067$ & $0 / 03$ \\
\hline & Reduction of supervising and control & $0 / 067$ & $0 / 03$ \\
\hline & On the job education & $0 / 135$ & $0 / 06$ \\
\hline \multirow{4}{*}{$\begin{array}{l}\text { Secondary factors } \\
0 / 33\end{array}$} & Cooperation and participation & $0 / 551$ & $0 / 18$ \\
\hline & Organizational mood and belonging & $0 / 060$ & $0 / 02$ \\
\hline & Recognition and appreciation & $0 / 260$ & $0 / 08$ \\
\hline & Information, knowledge and ability & $0 / 129$ & $0 / 04$ \\
\hline \multirow{3}{*}{$\begin{array}{l}\text { Occupational factors } \\
0 / 21\end{array}$} & Occupational background & $0 / 637$ & $0 / 14$ \\
\hline & Occupational tedium & $0 / 258$ & $0 / 05$ \\
\hline & Opposition of role & $0 / 105$ & $0 / 03$ \\
\hline
\end{tabular}

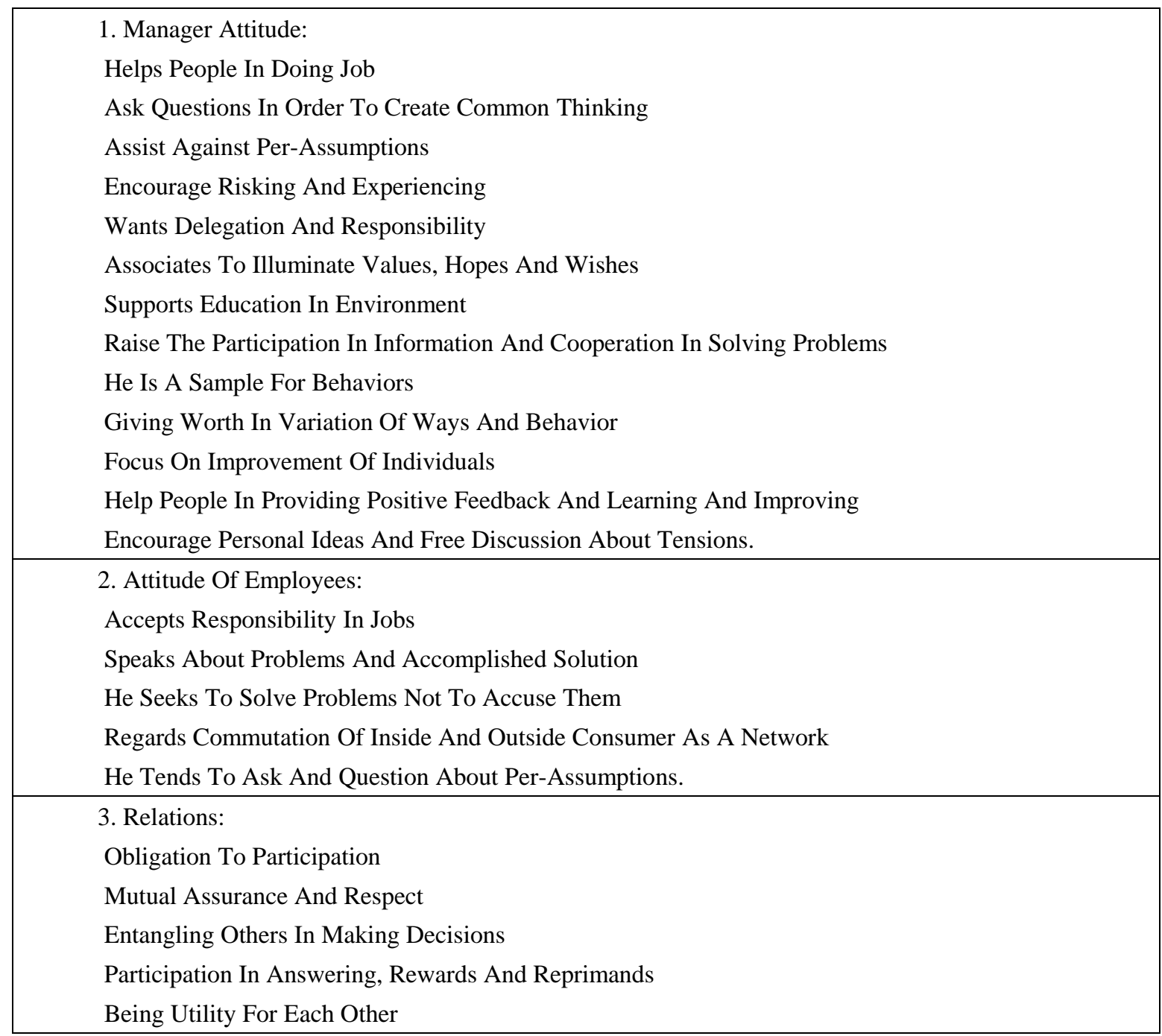




\begin{tabular}{|l|}
\hline Relation Between Important Information \\
Education In Parts \\
Focus On Process And Education. \\
\hline 4. Organizational Structure: \\
Systems Of Rewards \\
Common Values \\
Focus On Human Investment \\
Work Independency And Job Inflexibility \\
Obligation Towards High Quality Of Services To Customer \\
Obligation Towards Communication \\
Creating Association \\
Strategy For Working Tensions And Improving Job.
\end{tabular}

Figure 1. Model of empowering employees, Jaffe and Scott (1992)

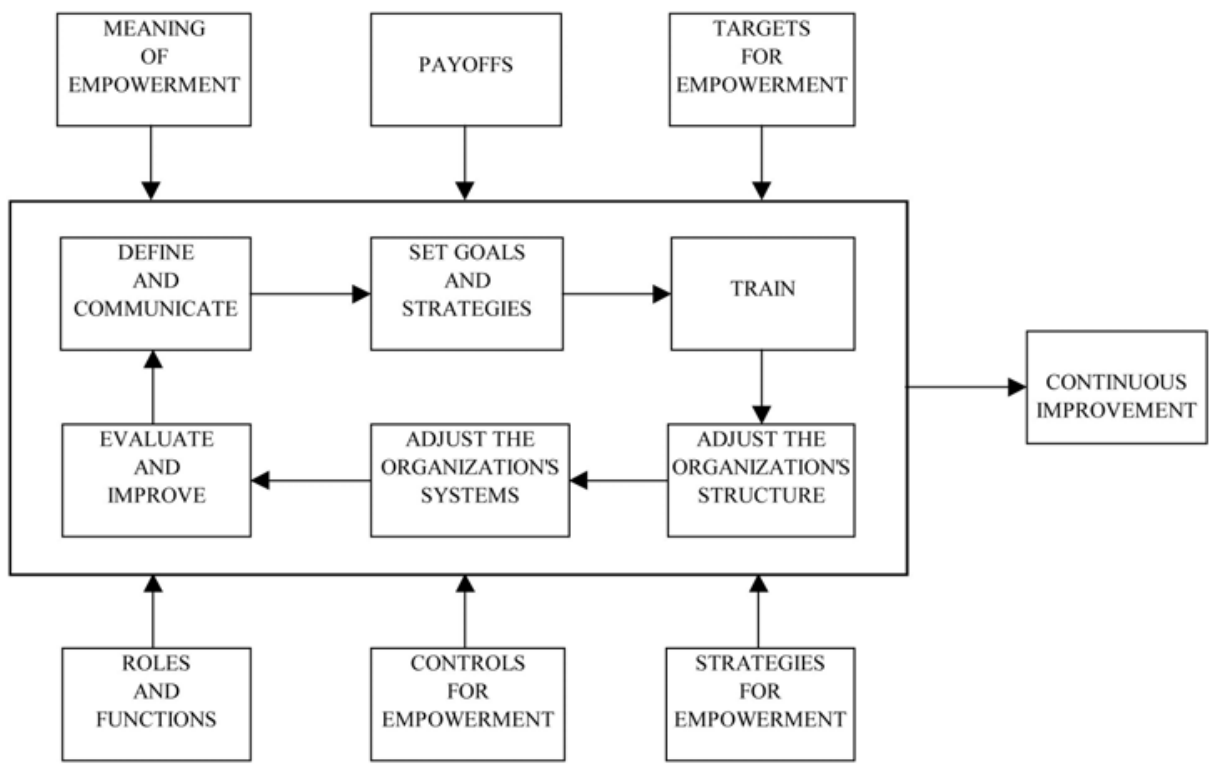

Source: Kinlaw (1995)

Figure 2. Model of empowering employees, Kinlaw (1995) 


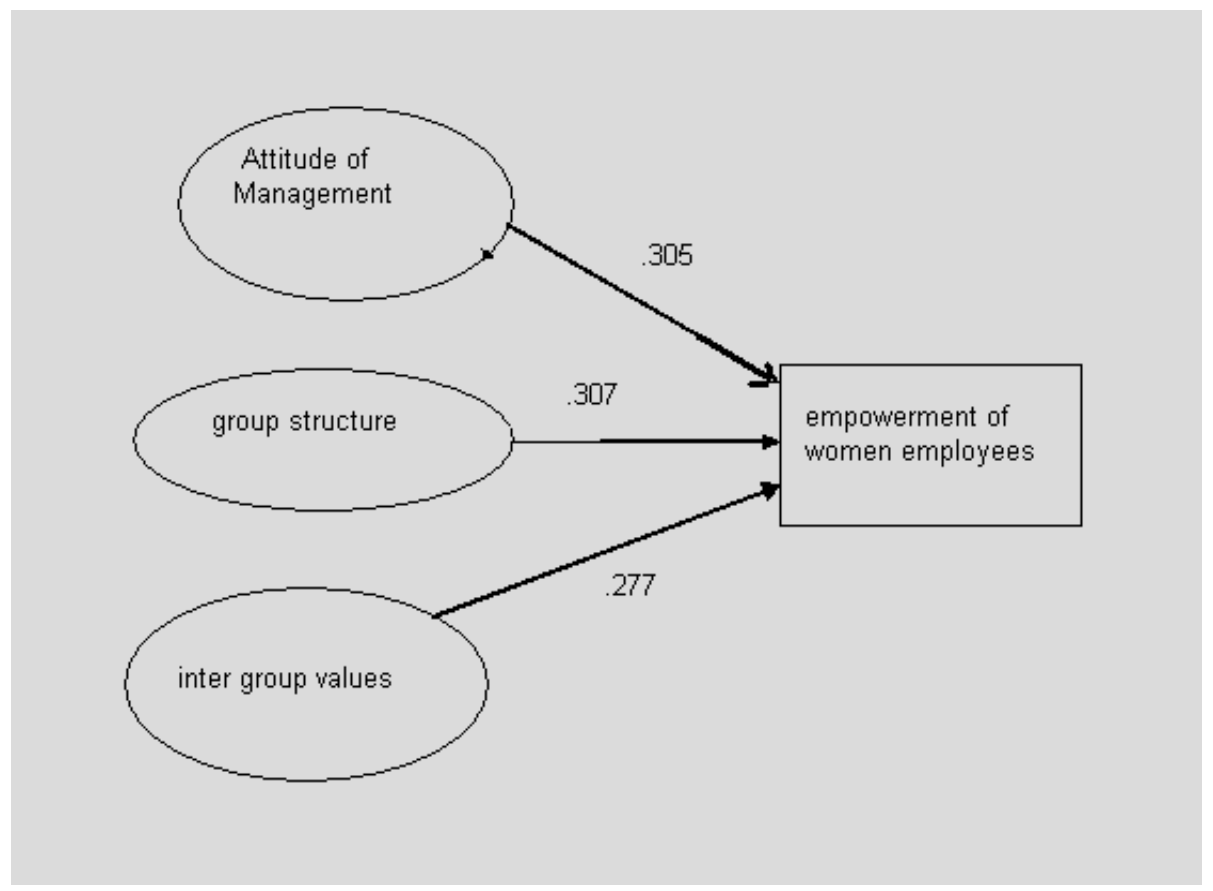

Figure 3. Model of empowering employees, Rahnamood and Husseini (2008)

\begin{tabular}{l}
$\begin{array}{l}\text { Ability Feeling } \\
\text { validness } \\
\text { strengthening } \\
\text { suitability and } \\
\text { information; } \\
\text { knowing himself } \\
\text { in the group: } \\
\text { encouraging and } \\
\text { challenging } \\
\text { attitude to job }\end{array}$ \\
$\begin{array}{l}\text { Branch of field: } \\
\text { organizational } \\
\text { environment: } \\
\text { organizational } \\
\text { culture. }\end{array}$ \\
\hline
\end{tabular}

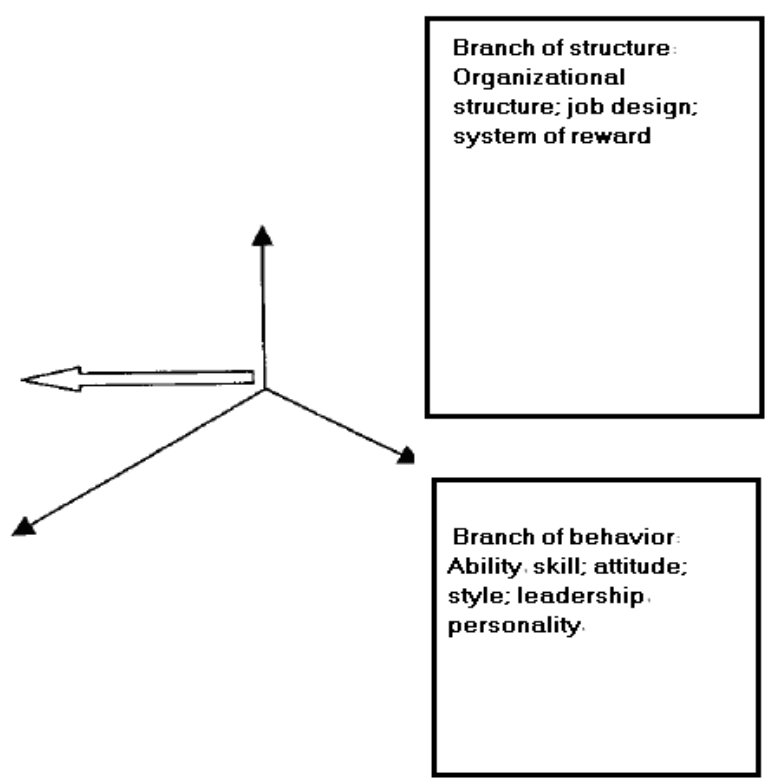

Figure 4. Model of empowering employees, Asgari (2004) 


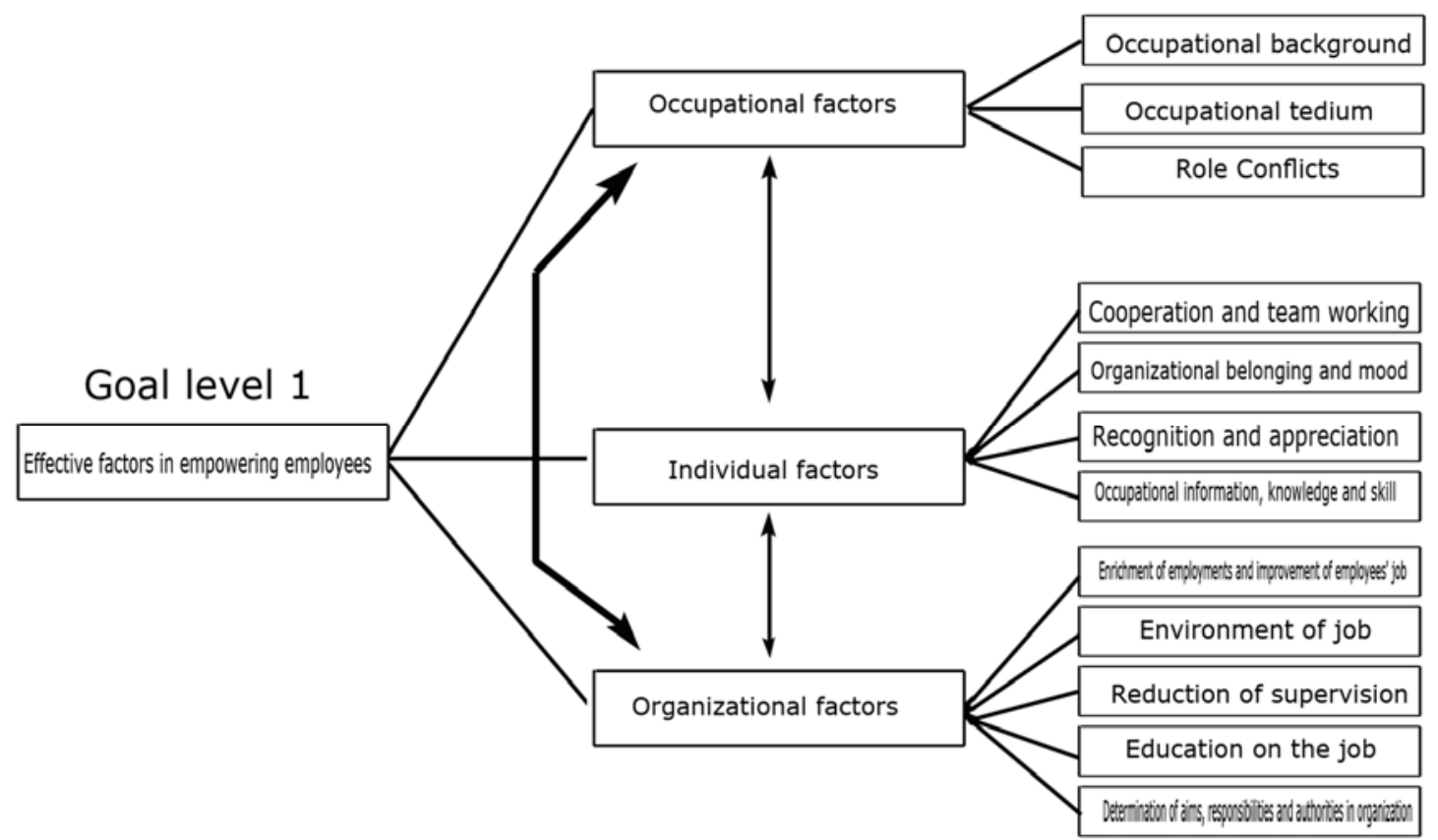

Figure 5. Structure of Empowering in this paper 